\title{
PROSES POLITIK DALAM PENYUSUNAN PERATURAN DAERAH (PERDA) ANGGARAN PENDAPATAN DAN BELANJA DAERAH (APBD) DKI JAKARTA TAHUN 2015
}

\author{
Efriza $^{*}$; Tri Rachmanto Supena \\ Sekolah Tinggi Ilmu Pemerintahan Abdi Negara (STIP-AN), Jakarta \\ *)email: efriza.riza@gmail.com
}

Paper Accepted: 30 Juni 2021 Paper Reviewed: 01-08 Juli 2021 Paper Edited: 09-14 Juli 2021 Paper Approved: 16 Juli 2021

\begin{abstract}
ABSTRAK
Anggaran Pendapatan dan Belanja Daerah (APBD) adalah rencana keuangan tahunan Pemerintah Daerah yang disetujui oleh Dewan Perwakilan Rakyat Daerah (DPRD), yang ditetapkan dalam bentuk Peraturan Daerah (Perda). Dalam dinamika proses politik terjadinya konflik antara Gubernur DKI Jakarta dengan DPRD DKI Jakarta, konflik ini terjadi dalam Penetapan APBD Tahun 2015. Penelitian ini menggunakan metode kualitatif. Penelitian ini menjelaskan APBD merupakan suatu rencana tahunan daerah yang dibahas dan disetujui bersama oleh pemerintah daerah (Gubernur) dengan DPRD yang selanjutnya ditetapkan menjadi Perda APBD. APBD yang disusun dan ditetapkan ini dilaksanakan oleh pemerintah daerah. Segala aktivitas yang dilaksanakan oleh Pemerintah Daerah berdasarkan pada desain pembangunan dan alokasi anggaran yang memerlukan persetujuan DPRD, sehingga dalam prosesnya dari rangkaian aspirasi masyarakat yang telah diperjuangkan dan dijadikan input (masukan) untuk kebijakan dalam penyusunan proses politik anggaran bagi Pembangunan Daerah, maka dinamika yang terjadi dalam proses politik haruslah diselesaikan bersama seperti dalam kasus Perda APBD Tahun 2015, jika tak ingin Pemerintah menggunakan Pagu Anggaran tahun sebelumnya dengan melalui dikeluarkannya Peraturan Gubernur yang malah dapat memeruncing konflik antar kedua institusi.
\end{abstract}

Kata Kunci : Konflik, DPRD, Gubernur DKI Jakarta, Perda APBD

\section{PENDAHULUAN}

\section{Latar Belakang}

Relasi Kekuasaan atau hubungan kerja antara Pemerintah Daerah dan Dewan Perwakilan Rakyat Daerah (DPRD) merupakan hubungan kerja yang kedudukannya setara dan bersifat kemitraan. Kedudukan yang setara bermakna di antara pemerintah daerah dan lembaga pemerintahan daerah itu memiliki kedudukan yang sama dan sejajar, artinya tidak saling membawahi. Hal ini tercermin dalam membuat kebijakan daerah berupa Peraturan Daerah (Perda). Sedangkan, hubungan bersifat kemitraan berarti DPRD merupakan mitra kerja pemerintah daerah dalam membuat kebijakan daerah, sehingga kedua lembaga wajib memelihara dan membangun hubungan kerja yang harmonis.

Hubungan kerja antara Pemerintah Daerah dan DPRD utamanya di DKI 
Jakarta sempat terjadi peristiwa yang begitu memanas. Dalam proses penyusunan Anggaran Pendapatan dan Belanja Daerah (APBD) DKI Jakarta 2015, Gubernur DKI Jakarta saat itu Basuki Tjahaja Purnama (Ahok) dianggap melakukan upaya memangkas fungsi dewan yakni fungsi pembentukan peraturan daerah (perda), anggaran, maupun pengawasan terhadap pelaksanaan peraturan daerah itu sendiri. Sehingga atas dasar itu, sesuai hak yang diatur oleh konstitusi, seluruh anggota DPRD sepakat untuk menggunakan fungsinya yaitu Hak Angket, (Wartaekonomi.co.id, 2015).

Terhadap hak angket yang saat itu sedang berjalan, DPRD mengharapkan semua pihak, termasuk Kementerian Dalam Negeri (Kemendagri) selaku koordinator penyelenggaraan pemerintahan daerah dapat menghormati dan menghargai proses yang diatur oleh Undang-Undang tersebut. Kendati demikian, Kemendagri berhak untuk melakukan evaluasi terhadap Rancangan Peraturan Daerah (Raperda) APBD DKI 2015 yang diajukan oleh Gubernur DKI (Ahok).

Dalam hal evaluasi Rancangan Perda APBD DKI 2015, dari pihak DPRD ingin menegaskan Raperda itu bukanlah Raperda yang disepakati oleh Gubernur (Ahok) dan DPRD DKI Jakarta yang ditetapkan pada 27 Januari 2015, (kompas.com, 2015). Oleh karena itu, proses evaluasi itu diserahkan kepada Kemendagri. Harapan besarnya adalah masyarakat DKI segera memiliki APBD agar pelayanan kepada masyarakat tidak terganggu. Terhadap perseteruan itu, tentunya Kemendagri telah mencermati proses politik yang sedang berlangsung di DKI Jakarta terkait proses penyusunan Rancangan Perda APBD Tahun Anggaran 2015.

Kericuhan yang terjadi itu juga tak bisa dilepaskan dari bentuk atas ketegangan komunikasi politik antara anggota DPRD dengan Kepala Daerah yang saat itu dipimpin oleh Ahok selaku Gubernur DKI Jakarta. Naik-turun, panas-dingin, hubungan legislatif dan eksekutif sebenarnya adalah hal yang lumrah terjadi. Itu terjadi antara lain karena tugas utama badan legislatif terletak di bidang perundang-undangan dan melakukan pengawasan terhadap eksekutif. Misalnya, untuk membahas rancangan undang-undang sering dibentuk panitia (panitia kerja atau panitia khusus) yang berwenang untuk memanggil menteri dan pejabat lainnya untuk diminta keterangan seperlunya.

Tetapi dewasa ini telah terjadi gejala umum bahwa titik berat badan legislatif telah banyak bergeser ke tangan badan eksekutif. Mayoritas dari perundangundangan dirumuskan dan dipersiapkan oleh badan eksekutif, sedangkan badan legislatif tinggal membahas dan merevisi atau menolaknya. Ketika terjadi ketegangan antara badan eksekutif dan legislatif, maka muncul konflik. Seperti disinyalir adanya 'dana siluman,' demi menyelamatkan dana APBD dari kebocoran dalam proses APBD DKI 2015, membuat anggota DPRD DKI Jakarta semakin berkonflik dengan Gubernur (Ahok), (kompas.com, 2015).

Permasalahan politik yang muncul ini adalah tentang polemik Rancangan Anggaran Pendapatan dan Belanja Daerah (RAPBD) 2015 DKI Jakarta (Triwaksana Sani, 2015). Pangkal persoalan konflik ini dimulai dari sebagian kalangan DPRD DKI Jakarta yang menilai Gubernur DKI Jakarta Ahok, menyalahi prosedur pengiriman APBD 2015 yang telah disahkan dalam Rapat Paripurna pada tanggal 27 Januari ke Kemendagri (Suriyanto, 2015).

APBD 2015 sebesar Rp78,03 triliun yang telah disahkan dalam Paripurna itu langsung di kirim Pemerintah Provinsi (Pemprov) DKI Jakarta tanpa dibahas kembali bersama DPRD DKI Jakarta. DPRD DKI Jakarta mensinyalir ada perbedaan antara APBD yang disahkan dalam rapat paripurna dengan APBD yang dikirimkan ke Kemendagri. Draft APBD 2015 tersebut juga dikembalikan oleh Kemendagri karena dinilai kurang memenuhi syarat teknis (Cnnindonesia.com, 2015).

Kurangnya komunikasi antara Pemprov DKI Jakarta dengan DPRD DKI Jakarta juga diduga sebagai salah satu 
penyebab kisruh Rancangan APBD (RAPBD) DKI Jakarta ini tak kunjung usai (Cnnindonesia.com, 2015). Selain itu, relasi antara Ahok dan DPRD DKI Jakarta, semakin menarik dicermati terutama karena gaya komunikasi sang gubernur yang khas. Banyak pihak menilai, gaya komunikasi Ahok, yang kerap berbicara ceplas-ceplos, blak-blakan dan straight to the point, yang dianggap kurang sopan. Bahkan, ada sebagian kalangan yang menyebutnya kasar (Lely Arrianie, 2010, 14-15).

Akhirnya, akibat konflik DPRD DKI Jakarta dan Gubernur Ahok tersebut, menyebabkan proses R-APBD yang belum selesai diurus tersebut membuat dana APBD tak kunjung cair, hal ini dapat menyebabkan terganggunya pembangunan infrastruktur daerah (DKI Jakarta).

\section{Perumusan Masalah}

1. Apa saja yang mempengaruhi dan menghambat proses penyusunan Peraturan Daerah APBD Tahun 2015 sehingga terjadinya konflik antara DPRD dan Gubernur DKI Jakarta?

2. Bagaimana relasi kekuasaan DPRD dan Gubernur DKI Jakarta dalam proses penyusunan Peraturan Daerah APBD tahun 2015 di era kepemimpinan Basuki Tjahaja Purnama dan Djarot Syaiful Hidayat?

\section{Maksud dan Tujuan Penelitian}

1. Untuk mengetahui dan memahami tentang permasalahan dari Raperda APBD Tahun 2015 DKI Jakarta yang hangat diperbincangkan oleh masyarakat dan juga sosial media.

2. Untuk mengetahui apa yang menyebabkan timbulnya konflik dalam relasi kekuasaan antara DPRD dan Gubernur DKI Jakarta.

\section{Waktu dan Tempat Penelitian}

Bahan penelitian (obyek penelitian) adalah lembaga DPRD, dengan unit analisisnya adalah mengenai proses penyusunan Perda APBD utamanya adalah Perda APBD tahun 2015 lalu. Sehingga dari obyek penelitian juga menjelaskan bahwa waktu dan tempat penelitian adalah Kantor DPRD DKI Jakarta, dengan alasan dari pemilihan lokasi ini sebab proses R-APBD dan konflik antara DPRD dan Gubernur DKI Jakarta terjadi di Kebon Sirih (Gedung DPRD DKI Jakarta). Berdasarkan pemahaman akan obyek penelitian dan unit analisis, serta lokasi penelitian ini, tentu saja akan mempermudah penulis dalam melakukan proses pengumpulan data dan proses analisis data, guna menjawab rumusan permasalahan penelitian yang diajukan dalam penelitian ini.

\section{METODE PENELITIAN}

Desain penelitian merupakan kerangka atau perincian prosedur kerja yang akan dilakukan pada waktu meneliti. Sehingga diharapkan dapat memberikan gambaran dan arah yang akan dilakukan dalam melaksanakan penelitian tersebut, serta memberikan gambaran jika penelitian itu telah jadi atau selesai penelitian tersebut dilakukan. Desain penelitian yang dirancang dalam penelitian ini menggunakan pendekatan kualitatif.

Pendekatan kualitatif disebutkan bahwa proses penyelidikan yang ilmiah melalui pengumpulan, pengolahan, analisis, dan penyimpulan data berdasarkan pendekatan metode, dan teknik tertentu guna menjawab suatu permasalahan, (Zainal Arifin, 2012: 2). Pendekatan kualitatif juga dijelaskan bahwa, suatu proses yang digunakan untuk mengumpulkan dan menganalisa informasi guna meningkatkan pemahaman kita pada suatu topik, (Imam Gunawan, 2013: 79). Tingkah laku, cara pandang, motivasi dan sebagainya secara menyeluruh dan dalam bentuk kata-kata, bahasa pada suatu kejadian-kejadian khusus artinya pendekatan dalam penelitian ini tidak menggunakan angkaangka (Burhan Bungin, 2003: 42). Penelitian kualitatif bertujuan untuk mengumpulkan informasi aktual secara rinci, dan melukiskan realita yang ada, (Jalaludin Rakhmat, 2000: 25).

Dalam penelitian ini, penulis menentukan persyaratan untuk deskriptif 
kualitatif terhadap informan yang akan diwawancarai yakni: pertama, anggota DPRD DKI Jakarta Periode 2014-2019; kedua, anggota DPRD DKI Jakarta yang lebih dari tiga kali mengikuti sidang paripurna dengan kehadiran Gubernur Ahok; dan ketiga, anggota DPRD DKI Jakarta yang pernah berkomunikasi dengan Ahok tidak hanya dalam kegiatan formal, tapi juga informal, seperti menghadiri jamuan makan malam, makan siang, atau coffee morning yang dihadiri oleh Ahok.

Berdasarkan kriteria informan yang akan diwawancarai tersebut, diharapkan penelitian ini dapat memperoleh hasil yang tepat untuk menjawab permasalahan penelitian ini. Di samping itu, selain anggota-anggota DPRD DKI Jakarta yang dijadikan informan, penelitian ini juga menentukan informan dari akademisi politik (pengamat politik), dan juga informan yang berasal dari lingkungan pemerintahan daerah DKI Jakarta. Upaya yang dilakukan dalam penelitian ini dengan menambahkan beberapa informan dari berbagai kategori lainnya adalah agar penelitian ini dapat memperoleh gambaran yang secermat mungkin dalam memperoleh hasil penelitian ini.

\section{HASIL PENELITIAN DAN PEMBAHASAN}

\section{Proses Politik Dalam Penyusunan Perda APBD Tahun 2015 Provinsi DKI Jakarta}

Dalam proses penetapan Perda APBD Tahun 2015 setelah dilakukan pembicaraan pada tahapan I, dilanjutkan dengan pembicaraan tahapan II yang berorientasi pada finalisasi Raperda APBD Tahun 2015 dan Penetapan Perda tentang APBD DKI Jakarta. Adapun kegiatannya meliputi: pertama, pengambilan keputusan dalam rapat paripurna yang didahului dengan: (a). Penyampaian Laporan Badan Anggaran (Banggar) terhadap proses finalisasi Pembahasan Raperda tentang APBD Tahun 2015; dan (b). Penyampaian pendapat akhir fraksi terhadap Raperda tentang $\mathrm{APBD}$, dalam proses ini juga perlu dipertegas bahwa dalam pembentukan fraksi yang diamanatkan di dalam undang-undang bahwa secara tidak langsung akan terbentuk kelompokkelompok yang memiliki visi dan misi yang berbeda dari kepentingan masyarakat dan proses ini sarat akan kepentingan politik. Meski keterwakilan fraksi telah ada di dalam Banggar tetapi tetap diperlukan permintaan persetujuan dari anggota secara lisan oleh pimpinan rapat paripurna. Kedua, Penyampaian pendapat akhir Gubernur terhadap Raperda tentang APBD Tahun 2015 yang telah disetujui DPRD DKI Jakarta.

Pada tahapan penyampaian laporan hasil kerja Banggar DPRD Provinsi DKI Jakarta terhadap Raperda APBD Tahun Anggaran 2015 dalam rapat paripurna DPRD dilakukan juga sekaligus persetujuan dewan dan pendapat akhir Kepala Daerah. Pada tahapan akhir setelah diperoleh persetujuan bersama dengan DPRD DKI Jakarta, kemudian dilanjutkan dalam proses evaluasi yang dilakukan oleh Menteri Dalam Negeri (Mendagri).

Proses Penetapan Perda APBD baru dapat dilakukan jika Mendagri menyatakan bahwa Perda APBD tidak bertentangan dengan kepentingan umum dan peraturan Perundang-Undangan yang lebih tinggi. Dari hasil evaluasi terhadap Rancangan APBD Provinsi DKI Jakarta Tahun 2015 yang dilakukan oleh Kemendagri masih banyak kasus ditemukan yaitu terdapat ketidaksesuaian antara alokasi anggaran dengan Kebijakan Umum Anggaran Prioritas Plafon Anggaran Sementara (KUA PPAS) dengan Raperda tentang APBD dan Rancangan Peraturan Kepala Daerah tentang penjabaran APBD.

Hal ini disebabkan pemerintah daerah dan DPRD belum konsisten menganggarkan program dan kegiatan pada setiap tahapan perencanaan yang telah disepakati mulai dari KUA PPAS dan R-APBD, (Sumelo Tumbo, 2012). Jika Raperda APBD tidak dapat diterima pada proses evaluasi, Pemerintah Daerah harus melakukan penyempurnaan dalam jangka waktu 7 Hari. Apabila telah dilakukan perubahan/penyesuaian, 
Kemendagri menyerahkan Raperda APBD beserta lampirannya dan Rancangan Peraturan Gubernur tentang penjabaran APBD yang telah sesuai dengan Perkemendagri tentang evaluasi Raperda kepada Gubernur.

Proses politik dalam pembahasan Raperda APBD terjadinya dinamika yang sebenarnya merupakan hal wajar terjadi, karena DPRD DKI Jakarta melalui Banggar DPRD DKI Jakarta dalam penggunaan fungsi legislasi dan politik anggaran merupakan lembaga perwakilan politik rakyat, sehingga pembahasan Perda APBD yang dilakukan bersama dengan Tim Anggaran Pemerintah Daerah dapat menampung dan mengakomodir aspirasi masyarakat secara komprehensif. Maknanya yaitu aspirasi, keinginan dan kebutuhan masyarakat yang telah dijaring, diakomodir dan dielaborasi oleh anggota DPRD DKI Jakarta ketika saat reses dan kunjungan kerja ke tengah masyarakat.

Aspirasi masyarakat telah diperjuangkan dan dijadikan input (masukan) untuk kebijakan dalam penyusunan proses politik anggaran untuk Pembangunan Daerah, sehingga pada akhirnya Perda APBD tahun 2015 yang disahkan akan mempunyai konstribusi positif kepada kepentingan, keinginan dan kebutuhan masyarakat dan Pemerintah Provinsi DKI Jakarta.

\section{Analisa Konflik Gubernur dengan DPRD dalam Proses Penyusunan APBD Tahun Anggaran 2015}

Apabila politik diartikan sebagai gejala manusia dalam rangka mengatur hidup bersama maka esensi politik sebenarnya juga suatu komunikasi. Komunikasi juga acapkali menyebabkan konflik. Konflik merupakan sebuah situasi dimana adanya gejolak antar individu dengan individu atau kelompok dengan kelompok. Situasi tersebut dapat memberikan dampak yang positif maupun negatif bagi berjalannya suatu keadaan di lingkungannya.

Hal ini, juga dapat terjadi di lingkungan pemerintah daerah yang menjalankan kegiatan pemerintahan yaitu antara badan eksekutif (Gubernur) dengan badan legeslatif (DPRD), hubungan antara kepala daerah dengan DPRD sebaiknya harus dapat berjalan seimbang dan harmonis agar terciptanya suatu pemerintahan yang baik (Good Goverment). Namun, hal tersebut bertolak belakang dengan apa yang terjadi di pemerintahan DKI Jakarta bahwa terjadinya konflik antara Gubernur DKI Jakarta Basuki Tjahaja Purnama dengan anggota DPRD DKI Jakarta Periode 2014-2019, hubungan yang terjadi di antara keduanya sangat tidak harmonis dan sering terjadi suatu gejolak yang semakin memanas.

Konflik antara Ahok selaku Gubernur dan DPRD DKI Jakarta pada dasarnya tidak hanya terjadi pada saat Ahok menjabat sebagai gubernur, tetapi telah dimulai sejak dirinya menjabat sebagai wakil gubernur DKI Jakarta, dari situasi ini tentu saja akan menjawab permasalahan penelitian dari penulisan penelitian ini.

Bagi Anggota DPRD DKI Jakarta Yuke Yurike, masalah yang terjadi dalam proses politik disebabkan oleh pengambilan data yang perencanaannya tak begitu konkrit. "Masalah proses politik acapkali menjadi kendala adalah salah satunya pengambilan kelengkapan data yang kurang konkrit seperti data Eksternal maupun data Internal. Data Internal terkait dengan sumber dana dikarenakan pembuatan ini membutuhkan dana yaitu misalnya dana untuk membuat kajian ilmiah yang melibatkan para pakar atau tenaga ahli yang ikut serta dalam pembentukan peraturan daerah. Data Eksternal itu terkait data di lapangan karena suatu peraturan daerah itu harus didukung data-data" (Hasil Wawancara Yuke Yurike, 2019).

Sedangkan Informan Johny Simanjuntak menyatakan proses politik acap terkendala dari DPRD itu sendiri, karena perilaku anggota DPRD yang kurang disiplin selain terkendala dalam proses perancangannya. "Seringkali terkendala dengan hambatannya dalam proses politik berasal dari DPRD itu sendiri seperti anggota DPRD sering terlambat dan tidak hadir. Selain juga yang menjadi kendala dalam memperoleh data yang dibutuhkan, berikutnya yakni 
pembentukan Perda yang sangat sulit dan njelimet serta banyak Raperda APBD yang diajukan tidak memenuhi kriteria dan persyaratan" (Hasil Wawancara Jhonny Simanjuntak, 2019). Meski begitu, pada pihak Eksekutif Daerah juga menjadi faktor penghambat karena seringnya membatalkan keputusan sepihak, "Kebuntuan terjadi, karena Ahok kerap 'membatalkan' kebijakan yang sebelumnya sudah disepakati Legislatif dan Eksekutif." (Hasil Wawancara Jhonny Simanjuntak, 2019).

Anggota DPRD DKI Dwi Wijayanto Rio Sambodo juga mengungkap permasalahan terjadi di legislator DPRD karena anggota DPRD kurang memahami keadaan dalam masyarakat itu sendiri. "DPRD memiliki banyak tugas dan fungsi yang memengaruhi kinerja DPRD dibidang legislasi. Namun, adanya pemahaman Pemerintah Provinsi DKI Jakarta melalui Satuan Kerja Perangkat Daerah (SKPD) lebih intelektual sehingga lebih banyak menguasai serta mengetahui keadaan atau masalah dalam masyarakat daripada DPRD itu sendiri" (Hasil Wawancara Dwi Wijayanto Rio Sambodo, 2019).

Sedangkan William Yani lebih menyoroti kendala secara komprehensif dalam proses politik pembuatan Perda. "Perda sering terkendala dengan tidak sesuainya dengan UndangUndang/Peraturan lainnya. Perda juga terkendala dengan Pemerintah yang tidak mendukung (Kabupaten, Kota/Pusat), Masyarakat juga tidak mendukung, selain juga keterbatasan anggaran yaitu biaya sosialisasi. Disamping itu, sulitnya mencapai kesepakatan antara Eksekutif dan Legislatif, Waktu/ketertiban kedua institusi dalam proses politik, dan kedisplinan waktu anggota DRPD" (Hasil Wawancara William Yani, 2019).

Faktor penghambat proses politik juga dijabarkan oleh Pantas Nainggolan terkait dengan permasalahan kourum di tingkat badan legislasi. "Tidak Kourumnya badan legislasi sehingga hasilnya tidak optimal, kajian tidak sesuai dengan kenyataan analisa, anggaran, sosial, alam dan lain-lain" (Hasil Wawancara Pantas Nainggolan, 2019). Proses politik penyusunan Perda juga terkendala dengan sinkronisasi dengan peraturan perundangundangan di atasnya, hal ini disampaikan Ketua Fraksi PDI Perjuangan Gembong Warsono, "kesulitan yang terjadi dan sering terkendala dalam mensinkronkan peraturan perundang-undangan diatasnya, misalnya, dapat sering berakibat sudah terjadi keputusan lalu dibatalkan" (Hasil Wawancara Gembong Warsono, 2019).

Sedangkan menurut Wakil Gubernur Djarot Saiful Hidayat terhadap proses politik antara Gubernur dan DPRD DKI Jakarta saat itu. Proses politik saat itu didalamnya sempat terjadi silang pendapat, kedua belah pihak saling serang untuk mempertahankan pendapatnya masing-masing, sehingga hubungan keduanya sangat tidak harmonis dan berjalan tidak seimbang karena tidak adanya saling mendukung dan berkomitmen bersama untuk membangun Jakarta lebih baik lagi (Hasil Wawancara Djarot Saiful Hidayat, 2019).

Berdasarkan Penelitian ini juga menemukan fakta bahwa gaya komunikasi Gubernur DKI Jakarta Ahok juga dianggap sebagai pemicu konflik. Sebab Ahok dianggap temperamental, emosional, kata-katanya kasar, akibatnya banyak membuat orang lain tersinggung, apalagi Ahok tipenya one man show. DPRD DKI Jakarta juga sudah mengingatkan semestinya gaya temperamentalnya diubah, karena dampaknya banyak melukai hati orang lain. Jangan merasa benar sendiri, sebagai pemimpin yang baik, harus mampu membangun komunikasi dengan semua pihak.

Pemimpin harus tegas, tetapi bukan berarti kita harus kasar. Gaya komunikasi Ahok tidak elegan, spontan, se-enak udelnya, ceplas-ceplos, blak-blakan, padahal apa yang dikatakan belum tentu yang dia pikirkan. Asal ceplos saja. Komunikasinya dianggap kurang baik. Jelang Pilkada, Ahok tersandung kasus surat Al-Maidah, sejak itu Ahok memang mulai berubah dalam berkomunikasi. Seperti diungkapkan oleh Informan dan sekaligus Ketua DPRD DKI Jakarta bahwa Ahok acapkali membuat komunikasi antara Eksekutif dan Legislatif buntu. "Ahok yang selalu curiga juga membuat 
komunikasi antara eksekutif dan legislatif acapkali buntu. Seperti, kok bisa-bisanya Gubernur mengklaim, kalau usulan dewan masuk wilayah 'dana siluman.' Padahal dewan mendapat usulan itu dari masyarakat melalui reses. Kalau ada satudua orang yang dimaknai Ahok bahwa usulan itu salah satu cara untuk mendapatkan proyek, silahkan proses hukum. Jangan semua disamakan. Jadi, permasalahan Ahok adalah ada di cara ia komunikasi. Sudah komunikasi nggak baik, kita tidak dihargai, curiga melulu, DPRD didudukkan di wilayah yang salah, padahal sebagai mitra, kita harus sama-sama membahas" (Hasil Wawancara Prasetio Edi Marsudi, 2019).

Kericuhan dalam perbedaan pendapat Eksekutif dan Legislatif memang acapkali ditenggarai oleh komunikasi dari Ahok itu sendiri, Anggota DPRD DKI Jakarta Gembong Warsono menyatakan, "Hal yang tidak menyenangkan saya dan teman-teman di dewan adalah saat dia menyebut "dana siluman" di Rancangan APBD Tahun 2015 jelas hanya tuduhan. Dia tidak bisa buktikan itu. Bahkan dia juga menyebut dewan perampok duit rakyat daerah. Itu tidak layak, buat seorang pemimpin berkata kasar dan men-judge. Makanya kita buat interpelasi, lalu angket. Saat kita mau naik dengar pendapat, PDI Perjuangan tidak mau, interpelasi pun tak jadi karena tidak kuorum" (Hasil Wawancara Gembong Warsono, 2019). Suasana juga semakin memanas ketika diupayakan mediasi oleh Kemendagri, “...Peristiwa pahit lain yang tidak bisa dia lupakan Gembong yakni, kegaduhan dalam mediasi terkait dana siluman APBD Tahun 2015 di Kemendagri. Ketika itu kedua belah pihak, anggota DPRD DKI Jakarta dan Ahok saling tuding. Ada yang berteriak dan memaki, rapat deadlock, (Hasil Wawancara Gembong Warsono, 2019).

William Yani juga secara pribadi pernah mengingatkan Ahok dengan ceritanya, “...tapi Ahok bilang, Gua kalau ngomong, ya ngomong dulu, kalau udah ngomong, dia bilang oh iya ya, saya ngomong salah. Saat dia terpeleset kasus Al-Maidah, dia lebih santun, dia mulai melunak. Ahok itu curigaan, dia bicara keras soal DPRD rampok, dana siluman. Apa itu tidak memfitnah dewan, menuduh tanpa bukti. Kalau dia bicara keras menuding DPRD rampok, apa itu tegas? Saya lihat dia hanya pencitraan. Tegas itu berkonotasi positif, tapi ini kan tidak" (Hasil Wawancara William Yani, 2019).

Prasetio sebagai Ketua DPRD DKI Jakarta juga pernah memberikan nasihat kepada Ahok, "...berkomunikasilah yang baik. Kalau Anda begitu terus, kesehatan jiwa Anda perlu diperbaiki. Dia malah marah, dia bilang, 'gua sudah lulus tes semuanya, tes kejiwaan saat Pilkada lulus'. Padahal kita kan nggak tahu, benar nggak itu lulus. William juga pernah mengkritik Ahok kalau dia tidak berbicara pada substansi, juga politisi William pernah arahkan" (Hasil Wawancara Prasetio Edi Marsudi, 2019). Harus diakui bahwa urusan gaya bicara pria yang bernama asli Basuki Tjahaja Purnama ini memang fenomenal. Bahkan, banyak orang jadi bertengkar gara-gara perbedaan pendapat soal gaya bicara Gubernur DKI Jakarta ini.

Sebagian orang menilai gaya bicara Ahok yang ceplas-ceplos sebagai komunikasi yang tidak sopan, kasar dan tidak menghargai orang lain. Tetapi ada juga yang menilai gaya bicara ini menunjukkan Ahok berbicara apa adanya, bahkan jujur. Yang jelas, akhirnya calon petahana Gubernur DKI ini sempat harus berurusan dengan meja hijau gara-gara gaya bicaranya terkait kasus Al-Maidah, hingga akhirnya sisa masa jabatannya diganti oleh Djarot Saiful Hidayat.

Dalam upaya mengetahui bagaimana konflik yang terjadi antara Gubernur DKI Jakarta dengan anggota DPRD, lalu dampak yang akan ditimbulkan apabila konflik tersebut tidak segera terselesaikan sampai dengan solusi yang dapat diberikan untuk mengatasi konflik tersebut. Maka akan dijelaskan kronologisnya, berdasarkan Ketua DPRD Prasetio, sebagai berikut.

- 27 Januari 2015, DPRD melalui sidang paripurna menyetujui APBD 2015 sebesar Rp 73,08 triliun. Jumlah tersebut meningkat 0,24 persen dibanding APBD 2014 yang 
berjumlah Rp 72,9 triliun. Tetapi, anggaran itu berkurang dari yang diajukan KUA-PPAS melalui surat Nomor 2525/-1.173 tanggal 13 November 2014.

- 2 Februari 2015, Pemprov DKI Jakarta pun langsung menyerahkan APBD Tahun 2015 yang telah disetujui bersama ke Kemendagri.

- 6 Februari 2015, Dokumen APBD Tahun 2015 yang diserahkan pada Kemendagri dikembalikan karena masih ada dokumen yang belum lengkap. Kemendagri sendiri sudah menerima berkas APBD Tahun 2015 Pemprov DKI Jakarta pada 5 Februari lalu, yang mana dokumen itu sudah dilengkapi surat persetujuan bersama dari DPRD DKI Jakarta.

- 9 Februari 2015, Ada oknum DPRD DKI Jakarta yang ikut campur tangan dalam pengajuan format APBD 2015 DKI Jakarta ke Kemendagri. Hal mana ada pihak legislatif secara diamdiam bersurat ke Kemendagri.

- 11 Februari 2015, DPRD DKI Jakarta karena mempermasalahkan ketiadaan tanda tangan mereka dalam dokumen APBD Tahun 2015 yang dikirimnya ke Kemendagri. Padahal, format yang diajukan Pemprov dengan sistem e-budgeting tidak memerlukan tanda tangan dewan di setiap lembarnya.

- 23 Februari 2015, Mendagri Tjahjo Kumolo mengirimkan tim untuk membantu menyelaraskan APBD Tahun 2015.

- 26 Februari 2015, DPRD DKI Jakarta menggelar paripurna pengajuan hak angket. Mereka akan bekerja dua bulan. Ada dua hal pelanggaran yang mendorong usulan hak angket ini, yakni: (1). Penyampaian Raperda tentang APBD Tahun 2015 kepada Kemendagri yang patut diduga bertentangan dengan ketentuan peraturan Perundangundangan; dan (2). Norma etika perilaku kepemimpinan Gubernur Provinsi DKI Jakarta. Badan Anggaran (Banggar) DPRD DKI Jakarta dan Tim Anggaran
Pemerintah Daerah (TAPD) melakukan evaluasi terhadap RAPBD DKI Jakarta Tahun 2015.

Selanjutnya, kekisruhan dalam Proses Politik antara Gubernur dan DPRD DKI Jakarta dalam penyusunan Perda APBD DKI Jakarta Tahun 2015 menimbulkan pertanyaan apakah dapat terwujud proses politik bersama atas RAPBD Tahun 2015 tersebut, disisi lain bahwa keputusan Kemendagri menyimpulkan untuk kembali menggunakan APBD DKI Jakarta Tahun 2014.

Dalam dinamika proses politik ini bagi Prasetio, bahwa pada Selasa, 27 Januari 2015 DPRD DKI Jakarta telah mengesahkan Rancangan Perda tentang APBD DKI Jakarta Tahun 2015 menjadi APBD DKI Jakarta Tahun 2015, dengan 13 catatan persyaratan dari Badan Anggaran (Banggar) untuk pihak eksekutif mempelajarinya, (Hasil Wawancara Prasetio Edi Marsudi, 2019).

- Penyelenggaraan Badan Penyelenggara Jaminan Sosial (BPJS) Kesehatan di DKI Jakarta yang masih menyisakan banyak masalah;

- Upaya peningkatan fasilitas Rumah Sakit Umum Daerah (RSUD) agar menjadi RSUD yang modern dan lengkap;

- Rencana untuk melanjutkan pembangunan stadion olahraga di Taman BMW (Bersih Manusiawi dan Berwibawa) yang sampai saat ini masih terdapat persoalan-persoalan yang belum terselesaikan secara hukum;

- Pemberian Kartu Jakarta Pintar (KJP) untuk sekolah swasta sebagai pengganti Biaya Operasional Pendidikan (BOP) yang dipandang belum mengakomodir kepentingankepentingan kelembagaan sekolah;

- Pelaksanaan pembebasan lahan untuk berbagai kebutuhan seperti pelebaran jalan, pemakaman, ruang terbuka hijau, dan lain-lain; yang dilaksanakan dalam bentuk satu kegiatan besar agar dapat direalisasikan dengan lebih cepat; 
- Peningkatan Pendapatan Asli Daerah (PAD) dan peningkatan taraf hidup masyarakat melalui pengembangan sistem transportasi yang melibatkan banyak stakeholder dan kepentingan menjadi sebuah rencana yang terpadu atau terintegritas dengan Rencana Tata Ruang;

- Pengembangan sistem transportasi yang terintegrasi di wilayah Kepulauan Seribu, mengingat Kepulauan Seribu merupakan Destinasi Pariwisata Unggulan di Provinsi DKI Jakarta;

- Optimalisasi perluasan dan penambahan jaringan jalan dan Missing Link, Prioritas penambahan armada angkutan Trans Jakarta, dan penataan trayek serta peremajaan angkutan umum;

- Penataan kampung dan kampung kumuh yang disertai dengan peningkatan kualitas lingkungan melalui penataan prasarana umum yang ada di lingkungannya;

- Persoalan sampah di DKI Jakarta yang sampai saat ini masih menjadi masalah yang belum terselesaikan, walaupun anggaran pengelolaan sampah setiap tahun mengalami peningkatan;

- Upaya peningkatan pengawasan pemanfaatan rumah susun dengan pembuatan kartu penghuni rusun multi fungsi, dan peningkatan pengamanan terhadap aset sarana dan prasarana rusun dengan program pemasangan CCTV (Closed Circuit Television);

- Kegiatan pembangunan Light Rail Transit (LRT) yang dimasukkan ke dalam APBD Tahun 2015 dipandang terlalu terburu-buru karena belum ada penjelasan tentang skema operasional dan Subsidi Tarif Proyek LRT kepada DPRD DKI Jakarta; dan

- Badan Anggaran juga memperhatikan Anggaran Kesejahteraan Pengurus RT/RW, dan penanggulangan bencana bagi Camat dan Lurah.

Dalam dinamika proses itu, saat itu Gubernur Provinsi DKI Jakarta pun mengucapkan terima kasihnya kepada
Dewan (DPRD DKI Jakarta) yang telah menerima usulan anggaran dari Pemerintah Provinsi DKI Jakarta.

Kalau DPRD DKI Jakarta memiliki fungsi mandiri berupa pengawasan dan perwakilan maka Kepala Daerah memiliki fungsi mandiri berupa pembuatan keputusan Kepala Daerah untuk menjabarkan Perda dan memimpin penyelenggaraan pemerintahan Daerah berdasarkan kebijakan yang ditetapkan bersama dengan DPRD. Yang dimaksud dengan penyelenggaraan Pemerintah Daerah ialah melaksanakan kebijakan publik, menegakkan Perda dan keputusan Daerah, memberikan pelayanan publik kepada warga masyarakat, mencari dan mengolah informasi yang diperlukan. Sehingga bagi Djarot Saiful Hidayat, bahwa Pemerintah Daerah berusaha menjabarkan Proses penginputan dana APBD Tahun 2015 menggunakan sistem e-Budgeting yang direncanakan akan dilakukan oleh Satuan Kerja Perangkat Daerah (SKPD) DKI Jakarta. Setelah proses input dengan sistem e-Budgeting rampung, hasil penyusunan draft APBD Tahun 2015 tersebut akan dibawa untuk kembali dibahas bersama dengan Badan Anggaran DPRD, hingga akhirnya terjadi keputusan bersama terkait Perda APBD DKI Jakarta (Hasil Wawancara Djarot Saiful Hidayat, 2019).

Akhirnya, kedua belah pihak pada Maret 2015 terjadi kesepakatan bersama dalam pembahasan dan evaluasi RAPBD 2015, sehingga dengan adanya kesepakatan bersama itu maka hasil pembahasan RAPBD 2015 akan disahkan menjadi Perda, dan tentu saja rencana Peraturan Gubernur untuk Penggunaan APBD Tahun 2014 tidak dilakukan. Sebab, pada dasarnya akan terjadi 10 (sepuluh) kerugian jika berdasarkan penggunaan Peraturan Gubernur tentang APBD Tahun 2015 hal mana menggunakan asumsi anggaran Tahun 2014, antara lain: (1). Karena menggunakan asumsi tahun 2014, maka bisa jadi duplikasi anggaran UPS sekitar Rp5 triliun masih teralokasi pada APBD. Tentu juga anggaran-anggaran pengadaan aneh lainnya; (2). Belajar dari rendahnya penyerapan APBD Tahun 2014 hanya 
$80 \%$, bisa jadi penyerapan akan semakin rendah. Perkiraan hanya 70\%-75\%; (3). Inovasi pelayanan publik tidak mendapat anggaran yang lebih banyak, misalnya peningkatan belanja Kartu Jakarta Sehat (KJS) dan Kartu Jakarta Pintar (KJP) serta sekolah gratis dan pengentasan kemiskinan; (4). Anggaran banjir tidak meningkat, justru stagnan sehingga dikhawatirkan DKI Jakarta masih dalam ancaman banjir; (5). Pembangunan DKI Jakarta akan macet, karena anggaran yang digunakan hanya untuk perawatan dan melanjutkan pembangunan sebelahnya; (6). Pembangunan MRT (Mass Rapid Transit) terancam terganggu karena tidak sesuai dengan kebutuhan pembangunan tahun 2015, sebesar Rp5 triliun dari APBD DKI Jakarta; (7). Pertumbuhan ekonomi DKI Jakarta tidak akan mencapai target 6.3\% karena anggarannya tidak mendukung, perkiraan hanya akan sampai di atas 5\% saja; (8). Pajak dari masyarakat tahun 2014 sepenuhnya tidak dapat digunakan untuk membiayai pembangunan dan pelayanan publik tahun 2015, padahal peningkatan pajak DKI Jakarta lumayan tinggi tahun 2014; (9). Potensi korupsi lebih tinggi apabila menggunakan asumsi APBD DKI Jakarta Tahun 2014, karena beberapa proyek sebelumnya terindikasi korupsi dan sudah diproses hukum, selain itu potensi SILPA (Sisa Lebih Pembiayaan Anggaran) yang tinggi juga menjadi celah korupsi; dan (10). Pada APBD Perubahan Tahun 2015 akan menjadi pertempuran sesungguhnya seluruh kepentingan politik, hal mana pendapatan akan meningkat tajam dan otomatis rencana belanja juga akan meningkat. Perubahan APBD ini biasanya menjadi pintu masuk korupsi, (Hasil Wawancara M. Sabil Rachman, 2019).

Peredaman emosi antara kedua belah pihak (Gubernur dan DPRD DKI Jakarta) juga sangat penting dengan tidak mengeluarkan statement yang tidak produktif, karena kehidupan pemerintahan menyangkut hubungan dengan publik sehingga pernyataanpernyataan yang disampaikan akan dapat dilihat oleh khalayak secara luas, maka perlunya pemikiran yang lebih rasional di antara kedua institusi ini. Semestinya berpikir dulu sebelum bertindak dan memikirkan apa dampak yang akan ditimbulkan jika mereka melakukan tindakan tersebut sehingga mereka dapat lebih menjaga ucapan dan sikapnya, sehingga Djarot memberikan Pesan dan Kesan Djarot atas kasus tersebut, "Pemerintah Provinsi DKI Jakarta bersama DPRD DKI Jakarta dalam menyusun Perda APBD Tahun 2015 memang harus memberikan beberapa hal kepada warganya seperti pendidikan gratis, kesehatan, lingkungan yang bersih, transportasi massal yang menjawab kebutuhan, dan lainnya, tetapi juga hak atas kota. Hak atas kota berarti hak terhadap kota itu sebagai sesuatu yang nyata, yang hadir dengan segala kerumitannya saat ini untuk kemudian mentransformasikan dan memperbaharui kota tersebut sesuai dengan konteks ekonomi politik kekinian" (Hasil Wawancara Djarot Saiful Hidayat, 2019).

\section{KESIMPULAN}

Proses politik dalam penyusunan dan penetapan Perda APBD di DKI Jakarta Tahun Anggaran 2015 lalu, telah disusun dan dilaksanakan sesuai dengan peraturan perundangan yang berlaku. Proses penyusunan dan penetapan APBD tidak hanya terjadi dalam proses-proses normatif dan empiris (visible proses) tetapi juga terjadi invisible process.

Pada pelaksanaan proses penyusunan dan penetapan APBD tahun anggaran 2015 terjadi ketidaktaatan pada fase penyusunan dan nota kesepakatan KUA PPAS serta pada fase penyusunan dan persetujuan RAPBD yang mengakibatkan output akhir penetapan APBD terlambat. Kelambatan juga terjadi karena adanya kericuhan dalam berbagai pendapat antara Gubernur dan DPRD DKI Jakarta.

Dalam proses itu juga terjadinya beberapa permasalahan seperti: komitmen yang rendah dari aktor yang terlibat dalam setiap proses serta tahapan penyusunan dan penetapan APBD yakni dari eksekutif dan legislatif, juga terjadinya konflik kepentingan antara eksekutif terkait proses pembahasan. Situasi ini juga terjadi karena belum dimilikinya sistem informasi yang terintegrasi mulai proses penyusunan 
dan penetapan Rencana Kerja Pemerintah Daerah (RKPD) sampai proses penyusunan dan pembahasan RAPBD, sehingga menyebabkan proses penyusunan membutuhkan waktu berlarut-larut yang menjadi sebab terlambatnya proses penyusunan dan penetapan APBD. Serta, disebabkan juga tidak adanya sanksi yang tegas terhadap aktor yang bertanggungjawab terhadap keterlambatan proses penyusunan dan penetapan APBD menjadi salah satu faktor menghambat penetapan APBD Tahun Anggaran 2015 tepat waktu.

Singkat kata, proses bersama antara DPRD dan Eksekutif (Kepala Daerah) keduanya juga menjadi faktor dari berlarut-larutnya proses penyusunan dan penetapan APBD Tahun Anggaran 2015 tersebut.

Dari hasil penelitian ini merekomendasikan perlu adanya manajemen koordinasi yang baik antar berbagai pihak yang berkepentingan dalam penyusunan APBD hal ini sangatlah diperlukan, dengan argumentasi: pertama, pihak-pihak yang terlibat dalam proses penyusunan APBD harus memiliki komitmen yang tinggi untuk menetapkan APBD secara tepat waktu serta melaksanakan anggaran yang telah ditetapkan dengan efektif dan efisien. Adanya komitmen memberikan gambaran bagi pihak yang terlibat dalam penyusunan APBD untuk mengetahui secara jelas visi, misi, tujuan, dan sasaran yang ingin dicapai dalam penyusunan APBD.

Selain itu, melalui komitmen dapat menciptakan motivasi dan kemauan bagi pihak penyusun APBD untuk menyelenggarakan tahapan penyusunan APBD yang lebih baik, efektif, efisien, dan sesuai dengan peraturan yang berlaku. Kedua, eksekutif dan kegislatif harus melakukan komunikasi dan koordinasi yang baik, menjalin hubungan kinerja dalam hal penganggaran keuangan daerah dengan pendekatan yang proaktif. Komunikasi antara eksekutif dan legislatif harus dilandasi transparansi, akuntabilitas dan saling menghormati antara berbagai pihak dan tidak mementingkan ego pribadi masing-masing. Semestinya hubungan kinerja dalam penganggaran keuangan daerah antara legislatif dan eksekutif harus berlangsung harmonis, karena relasi yang baik dari kedua lembaga akan mengurangi resiko tarik-ulur dalam penetapan anggaran dan mengurangi kepentingan politik tetapi juga perlunya turut meminimalisir terjadinya persekongkolan negatif.

Prinsip cheeks and balance antara eksekutif dan legislatif memang sangat diperlukan, namun juga eksekutif dan legislatif harus mempunyai komitmen untuk mentaati jadwal penetapan APBD sebagai bentuk komitmen kepedulian atas daerah. Ketiga, meningkatkan komunikasi vertikal maupun horisontal antara para penyusun APBD dari pihak eksekutif dan legislatif yakni secara formal maupun informal untuk mencegah keterlambatan APBD di tahun yang akan datang serta mewujudkan APBD yang lebih berkualitas.

\section{DAFTAR PUSTAKA}

Arrianie, Lely, Komunikasi Serba Ada Serba Makna, (Jakarta: Prenada Media Group, 2010).

Arifin, Zainal, Penelitian Pendidikan Metode dan Paradigma Baru, (Bandung: Remaja Rosdakarya, 2012).

Bungin, Burhan, Metodologi Penelitian Kualitatif, (Jakarta: Raja Grafindo Persada, 2003).

$\mathrm{CNN}$

Indonesia, http://www.cnnindonesia.com/na sional/20150307121300-20-

37421/soal-kisruh-apbd-dkipengamat-menilai-ahok-salahlangkah/

Gunawan, Imam, Metode Penelitian Kualitatif Teori dan Praktek, (Jakarta: Bumi Aksara, 2013).

Hasil Wawancara dengan Anggota PDI Perjuangan DPRD DKI Jakarta Dwi Wijayanto Rio Sambodo. Jum'at, 06 September 2019 di Kantor DPRD DKI Jakarta.

Hasil Wawancara dengan Anggota PDI Perjuangan DPRD DKI Jakarta Gembong Warsono. Jumat, 20 
September 2019. di Kantor DPRD DKI Jakarta.

Hasil Wawancara dengan Anggota PDI Perjuangan DPRD DKI Jakarta Jhony Simanjuntak, Rabu, 04 September 2019, di Kantor DPRD DKI Jakarta.

Hasil Wawancara dengan Anggota PDI Perjuangan DPRD DKI Jakarta Pantas Nainggolan, Rabu, 18 September 2019 di Kantor DPRD DKI Jakarta.

Hasil Wawancara dengan Anggota PDI Perjuangan DPRD DKI Jakarta William Yani, Rabu, 11 September 2019 di Posko Pemenangan William Yani (Kampung Gedong).

Hasil Wawancara dengan Anggota PDI Perjuangan DPRD DKI Jakarta Yuke Yurike, Senin, 02 September 2019 di Kantor DPRD DKI Jakarta.

Hasil Wawancara dengan Ketua DPRD DKI Jakarta dari PDI Perjuangan Prasetio Edi Marsudi, Selasa 01 Oktober 2019, di Kantor DPRD DKI Jakarta.

Hasil Wawancara dengan Akademisi Politik dan Politisi Partai Golkar M. Sabil Rachman, Dosen STIP-AN dan Sekretaris Jendral PPK Kosgoro 1957, pada Jumat 06 September 2019, , di STIP-AN, Jakarta.

Hasil Wawancara dengan Wakil Gubernur/Gubernur Djarot Saiful Hidayat, Selasa 01 Oktober 2019, di DPP PDI Perjuangan Diponegoro.
Kompas.com, Awal Kisah Perseteruan Ahok VS DPRD DKI, https://otomotif.kompas.com/rea d/2015/03/03/08420501/Awal.Ki $\underline{\mathrm{sah}}$.

Perseteruan.Ahok.Vs.DPRD.DKI

Kompas.com. Gubernur DKI Antara Retorika dan Sosok, http://megapolitan.kompas.com/ read/2015/05/27/15060061/Gube rnur.DKI. antara.Retorika.dan.Sosok

Rakhmat, Jalaludin, Metode Penelitian Komunikatif, (Bandung: Remaja Rosda Karya, 2000).

Suriyanto, Pantau dan Bandingkan Dua Versi APBD Jakarta, http://www.cnnindonesia.com/na sional/20150306035507-2037120/pantau-dan-bandingkandua-versi-apbd-jakarta-di-situs-ini/

Triwisaksana Sani, Polemik APBD DKI Jakarta 2015, http://politik.kompasiana.com/ 2015/02/23/polemik-apbd-dkijakarta-2015-memahami-prosespenyusunan-apbd--708312.html.

Tumbo, Sumelo, Permasalahan Aktual dalam Evaluasi APBD dan Solusinya, Media Keuangan Daerah, Jakarta: Direktorat Jenderal Keuangan Daerah Kementerian Dalam Negeri, 2012).

Warta Ekonomi, Menanti Ujung Palu Angket DPRD DKI, dalam https://www.wartaekonomi.co. id/read47573/menanti-ujungketukan-palu-angket-dprd-dki-ii 